\title{
A Summary of the Research on the Entrance Education of University Librarians in China in Recent Ten Years
}

\author{
Yuzhi Cao \\ Library, Binzhou University, Binzhou, China \\ Email:673062586@qq.com
}

How to cite this paper: Cao, Y.Z. (2019) A Summary of the Research on the Entrance Education of University Librarians in China in Recent Ten Years. Open Access Library Journal, 6: e5550.

https://doi.org/10.4236/oalib.1105550

Received: June 17, 2019

Accepted: June 30, 2019

Published: July 3, 2019

Copyright $\odot 2019$ by author(s) and Open Access Library Inc.

This work is licensed under the Creative Commons Attribution International License (CC BY 4.0).

http://creativecommons.org/licenses/by/4.0/

\begin{abstract}
This paper investigates the literature on the entrance education of college freshmen in China in the past ten years, analyzes and summarizes the research status of the entrance education of university library freshmen in the past ten years and the problems existing in the current research, and looks forward to the future research.
\end{abstract}

\section{Subject Areas}

Library, Intelligence and Philology

\section{Keywords}

University Library, Entrance Education, New Student

\section{Introduction}

The author investigates and summarizes the research status of the entrance education of university freshmen in the past ten years, and lays the foundation for future research and work. It is also a reference for the authors who do research in this area and the library colleagues who are currently working on this subject.

\section{Literature Survey Analysis}

The author's literature research is in the CNKI (China Knowledge Network) digital publishing platform, input title = "new student admission education" and title $=$ "(new education or freshman training) and library", the precise time limit is From January 1, 2009 to December 31, 2018, the restricted document types were "Journals" and "Meetings", and the search time was May 10, 2019. After 
deduplication and deletion of foreign literature, there were 248 articles, of which 246 were journal articles and 2 were conference papers.

\subsection{Annual Distribution}

In this literature survey, the annual distribution of the literature on the admission of freshmen to colleges and universities in China is shown in the following figure. From the number of documents in each year, the number of documents increased rapidly from 2009 to 2012, and the peak value reached 34 in 2012, about 143\% higher than in 2009. From 2012 to 2017, the number of documents was gradually reduced, and in 2018, it began to rise again (see Figure 1). From this line chart, we can see that the research on the entrance education of college freshmen in China has experienced the process from cold to hot to cold and then warm. Among them, the number of documents published in 2011-2014 accounted for $51 \%$ of the total number of documents, which is the hottest year in this field (see Figure 1). At the end of the last century, at the beginning of this century, colleges and universities expanded their enrollment. In the face of the surge in the number of new students, the original training modes of university libraries such as librarians and field trips are no longer suitable for the development of the new situation. With the popularity of the Internet, more and more colleges and universities have begun to use the Internet technology to create a new mode of admission training, so the number of papers has increased continuously during 2009-2012. As the model continues to shape, the number of papers has gradually decreased between 2013 and 2017. In the past two years, with the use of new technologies and concepts such as VR, relevant researchers have begun to combine them with new-born training and have produced new research results. As a result, the research results in 2018 have increased significantly.

\subsection{Research Topic Distribution}

According to the literature investigation and research, the research themes of the entrance education of college freshmen in China in the past ten years are mainly divided into the following aspects: new modes or new methods of new students entering the library, new technology applications for new students entering the

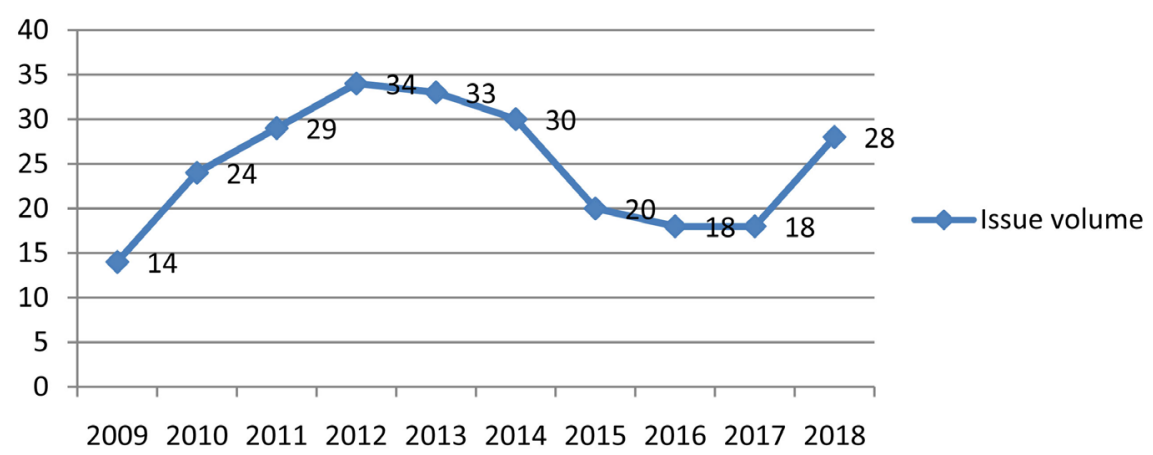

Figure 1. Annual distribution of articles published. 
library, the problems and improvement measures of the education of new students entering the libraries, the status quo and effect analysis of new students' admission education, and so on.

From the statistics of the data, it can be seen that the analysis of the problems and countermeasures of the new entrance education has the most articles, accounting for $39.9 \%$ of the total number of documents surveyed (see Table 1). It can be seen that there are certain problems in the current entrance education and the library staffvalue the innovative research in this area.

However, from the content point of view, there are many general talks and few innovations. From the perspective of publishing journals, the research topic has not been published in core journals. Secondly, it introduces the new models or new methods of new students' admission education, accounting for $30.6 \%$ of the total number of documents (see Table 1). This is the core issue of the new education. There are 40 articles that introduce the status quo and effect analysis of new students entering the library, most of which take a school as an example. In addition, there are 20 applications of new technologies in the education of new students. Most of them have been studied in the past six years. It also shows that there are more new technologies that can be applied to the education of new students in recent years. There are 11 articles introducing the importance of new students entering the library, mainly focusing on the first five years, indicating that the importance of new students entering the education in recent years has reached consensus (see Table 1).

Table 1. Thesis research topic annual distribution table.

\begin{tabular}{|c|c|c|c|c|c|c|c|c|c|c|c|c|}
\hline Research Topics & 2018 & 2017 & 2016 & 2015 & 2014 & 2013 & 2012 & 2011 & 2010 & 2009 & total & proportion \\
\hline $\begin{array}{l}\text { New models or new } \\
\text { methods for new students } \\
\text { entering the education }\end{array}$ & 12 & 4 & 6 & 8 & 9 & 12 & 9 & 7 & 5 & 4 & 76 & $30.6 \%$ \\
\hline $\begin{array}{c}\text { The application of new } \\
\text { technology in the education } \\
\text { of new students }\end{array}$ & 3 & 5 & 1 & 3 & 1 & 3 & 1 & 0 & 3 & 0 & 20 & $8.1 \%$ \\
\hline $\begin{array}{l}\text { Problems and Countermeasures } \\
\text { in the Education of Freshmen } \\
\text { Entering the Library }\end{array}$ & 10 & 6 & 8 & 7 & 11 & 12 & 16 & 13 & 9 & 7 & 99 & $39.9 \%$ \\
\hline $\begin{array}{l}\text { Analysis of the Status } \\
\text { Quo and Effect of Freshmen's } \\
\text { Entrance Education }\end{array}$ & 3 & 3 & 3 & 1 & 6 & 5 & 7 & 8 & 4 & 0 & 40 & $16.1 \%$ \\
\hline Importance & 0 & 0 & 0 & 0 & 3 & 0 & 1 & 1 & 3 & 3 & 11 & $4.4 \%$ \\
\hline $\begin{array}{l}\text { Combined with } \\
\text { reading promotion }\end{array}$ & 0 & 0 & 0 & 1 & 0 & 0 & 0 & 0 & 0 & 0 & 1 & $0.4 \%$ \\
\hline Review & 0 & 0 & 0 & 0 & 0 & 1 & 0 & 0 & 0 & 0 & 1 & $0.4 \%$ \\
\hline
\end{tabular}




\subsection{Distribution of Journal Sources}

According to the author's statistics, 248 articles on the entrance education of Chinese university libraries in the past ten years of this survey are distributed in 120 journals, with the core journal catalogue of Peking University (2017 edition) and CSSCI Chinese social science citation index (2019-2020) Based on the source journal catalogue (including the extended version), only 13 articles from core professional journals accounted for $5 \%$ of the total survey literature, respectively, in Library Science Research, Library Work and Research, and Modern Intelligence. The core journals of books and information (see Figure 2). 236 non-core journal articles, accounting for $95 \%$ of the total amount of research literature, mostly distributed in non-book-related general journals, including 29 articles published in the journal Science and Technology Information Development and Economy, accounting for $12 \%$ of the total literature.

\section{Innovation and Main Mode of Admission Education for Freshmen in Colleges and Universities in China}

Since the end of the 1990s, with the expansion of the enrollment scale of colleges and universities, the limited teachers of university libraries are difficult to meet the needs of teaching. The transformation and innovation of the new entrance education model has become an important task of university libraries. The decade of 2009-2018 that the author surveyed is precisely the stage in which college libraries actively combine new technologies and new media to seek a new mode of admission education. A comprehensive analysis of the 248 documents surveyed, whether it is related to the problems and countermeasures of new students entering the library, the status quo and effect analysis of new students entering the library, or the application of new technologies in the education of new students, will come down to Discussion on the mode or method of entering the education of new students.

\section{Source journal}
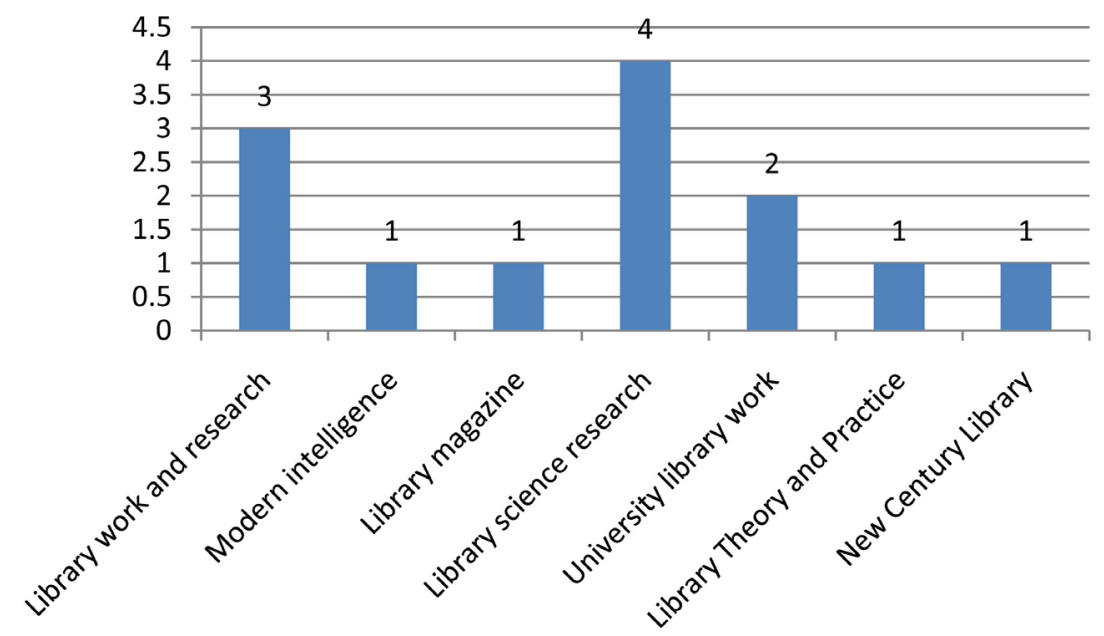

Figure 2. Core journals publish related articles distribution map. 


\subsection{Innovative Research on Freshmen's Entrance Education}

The innovative research on the admission of new students is reflected in the use of new technologies and the practice of new ideas.

The use of new technologies mainly includes VR technology, micro-class, Drupal platform and so on. Of the ten years of literature surveyed, 20 involved the application of new technologies. However, due to the acceleration of the upgrading of the technical field, some of the more advanced technologies at the time are now obsolete. For example, Wang Hong proposed in 2010 to build a CD-ROM system to deal with the new entrance education [1]. New technologies that have been popular in recent years have also been introduced or applied to the new entrance education of university libraries. For example, Xu Liang and Pan Xingxian analyzed the VR technology to stimulate educational thinking innovation in the new entrance education. They came up with ideas for the application of new technologies. For example, VRML 3D modeling perfectly presents the virtual environment, $360^{\circ}$ panoramic display of virtual reality, wearable and portable devices to help users IntelliSense, etc. At the same time, it also pointed out the problems of VR technology in the application of funds, librarian technical literacy and service literacy, new-adaptability and other issues [2]. Huang Min et al. proposed the use of micro-courses for freshmen's admission education, to achieve individual repeat learning, asynchronous mobile teaching, etc. [3]. Wang Linlin and others proposed to establish a library entrance education platform based on the Drupal operating system to realize the online acceptance of the entrance education training, the answering, and the automatic opening of the borrowing authority after the passing of the assessment [4].

The new ideas mainly include informal learning concepts, multiple intelligence theories, and the concept of integration and innovation under the framework of "Morality Education". For example, Yao Hong analyzes the unique advantages of informal learning, explores the integration of informal learning concepts into the environment, content, form and learning strategies of new admission education, and integrates emotional, contextual and ubiquitous education into college entrance education. Through the whole process of learning platform construction, situational resource organization, learning interest transfer, sharing space creation, librarian role integration and learning evaluation exploration, the author breaks through the objective, theoretical and practical conflicts in the entrance education of college freshmen. Promote the effective formation of open learning, resource-rich, spontaneous, interactive and evaluable ubiquitous learning methods [5]. Zhang Boxian proposed to introduce the theory of multiple intelligence education in the new entrance education, to personalize the new students, and truly teach students according to their aptitude [6]. Chen Youhua and others proposed to use the FYE plan and common reading project of foreign universities to design a fusion innovation model under the framework of "Morality Education" to realize the integration of education subject and object, multi-quality content integration, spatial platform integration and multi-educational form integration [7]. 


\subsection{The Main Mode of the New Entrance Education}

The innovation of the new entrance education must finally form an easy-to-promote model to be truly implemented in practice. Through research and analysis of the literature in the past ten years, the academic model of the new entrance education is mainly the network self-service platform, MOOC mode, SOLOMO mode, Moodle platform mode and WeChat public platform mode. For example, Wang Baoying conducted a survey and analysis of 27 "211 Project" college libraries that implemented online self-service freshmen admission education, and proposed to improve the a one-stop learning and testing platform, the multimedia technology and mobile phone platform, and the applications and building educational ports for different readerships [8]. Li Pei analyzed the feasibility of carrying out the MOOC model for university students to enter the library [9]. Chang Qing et al. elaborated on the implementation of new-enterprise education training on the basis of socialized local mobile application (SOLOMO), and designed an inter-access technology to realize heterogeneous platforms [10]. Zhu Xiao specifically introduced the practice of constructing a new-education education training model on the Moodle platform [11]. Zhang Xuemei analyzed the current situation of the development and use of the WeChat public platform in college libraries, and explored how to deeply explore the use of the WeChat public platform to carry out the new entrance education [12]. In general, the main mode of the newcomers' entrance education is to borrow an online platform to enrich the content of the admission education, and to realize online learning, exchange and interaction, and get borrowing rights.

\section{The Current Research Deficiencies}

\subsection{The Core Article Has a Low Proportion}

From the author's research, at present, the proportion of core articles on the entrance education of Chinese university libraries is low. In the 248 articles surveyed, the proportion of core articles is only 5\%; non-core articles are mostly distributed in non-library information. In the general journals, the level of research and the overall level of research need to be improved.

\subsection{Core Research Author and Key University Research Authors Are Few}

According to the surveyed articles, there are no high-frequency authors, and there are few core research authors. One author has published 3 articles, 13 authors have published 2 articles, and the remaining authors have published one. From the author's point of view, there are not many researchers in key universities. Among them, Wang Bo of Peking University Library has enriched the entrance education of new students from the perspective of reading and promotion [13]. Chen Youhua and Wang Luyi of Shanghai Jiao Tong University used the foreign model to combine the practice of the school to explore the fusion and innovation mode of the new education of university libraries under the frame- 
work of "Morality Education" [7]. Zhang Na of the Library of Northwest A \& F University introduced the mode of admission to the school [14]. Cao Fuyong introduced the investigation and model innovation of the freshman training of Sun Yat-sen University Library [15]. The entrance education models of key universities are often at the forefront, and sharing their case is a good way to communicate. But overall, the proportion of researchers in key universities is very small, and most of the authors are from ordinary undergraduate colleges and higher vocational colleges.

\section{Outlook}

By investigating the articles on the entrance education of university libraries in the period of 2009-2018, we can see that the research on the entrance education of freshmen has been rich in content and achieved certain research results. However, the existing problems in research are also obvious, such as the overall level of research. There are fewer authors of improvement and core research. In the future research, the author suggests that in addition to exploring the application of new technologies, we should also pay attention to the new library education to see and implement the university library service in a broader scope, thus strengthening the topical research, such as how to integrate the new entrance education into the new education system of the whole school, how to combine the new entrance education with reading promotion and information literacy education. In addition, it is hoped that the library staff of more key institutions will present the experience and achievements of the new entrance education in the form of articles for more researchers, practitioners to refer to and learn from.

\section{Conflicts of Interest}

The author declares no conflicts of interest regarding the publication of this paper.

\section{References}

[1] Wang, H. (2010) Design and Implementation of the New Education CD System in University Libraries. New Century Library, 44, 59-61.

[2] Xu, L. and Pan, X. (2018) Application of VR Technology in Library Entry Education for University Freshmen. Information Research, No. 244, 79-83.

[3] Huang, M. and Li, Y. (2017) Application of Micro Class in Library Freshmen's Entrance Education-Taking Hainan Normal University Library as an Example. Journal of Jiamusi Vocational College, No. 180, 478.

[4] Wang, L., Zhang, X. and Song, X. (2013) Drupal-Based Library Entrance Education Platform for New Recruits. Chinese Journal of Medical Library and Information Science, 22, 70-71, 78.

[5] Yao, H., Pan, X. and Gu, J. (2018) Exploration of Freshmen Education in University Library Based on the Idea of Informal Learning. Library Work and Study, No. 274, 74-78.

[6] Zhang, B. (2013) Talking about the Theory of Multiple Intelligences and the En- 
trance Education of Library Freshmen. Jiangxi Chemical Industry, No. 4, 352-354.

[7] Chen, Y. and Wang, L. (2018) Study on the Innovative Instruction Model of Academic Library for Freshman under the "Morality Education" Framework. Library Journal, 37, 58-63, 95.

[8] Wang, B. and Wang, B. (2017) Investigation and Analysis of the Status of Network Self-Service Library Entry Education for Freshmen in "211 Project" University Libraries. Library Work and Study, No. 262, 92-98.

[9] Li, P. (2017) Research on the Entrance Education of University Librarians Based on MOOC Mode. Henan Library Journal, 37, 51-53.

[10] Chang, Q. and Yang, W. (2018) Innovative Practice of Freshmen's Education in the SOLOMO Mode-Taking the Library of Zhejiang Agriculture and Forestry University as an Example. Information Research, No. 245, 100-104.

[11] Zhu, X. (2017) Construction of College Library Education and Training Mode for Freshmen Based on Moodle Platform-Taking Library Education and Training Mode for Freshmen in Zhenjiang College as an Example. Journal of Zhenjiang College, 30, 46-48.

[12] Zhang, X. (2015) On Using University Library's WeChat Public Platform to Conduct Library Entrance Education for Freshmen. Information Research, No. 215, 100-102, 106.

[13] Wang, B. (2015) Booklists Recommended to Freshmen in the Reading Promotion of University Libraries. Library and Information Studies, 8, 3-15.

[14] Zhang, N. (2011) Exploration on University Library Orientation for FreshmanTaking the Library of Northwest A \& F University as an Example. Journal of Library and Information Sciences in Agriculture, 23, 152-153, 157.

[15] Cao, F. and Jiang, X. (2010) Investigation on the Effect of Freshmen Training in University Libraries and Innovation of Training Model-Taking the Library of East Campus of Sun Yat-Sen University as an Example. Research on Library Science, No. 239, 85-88. 